\title{
Effects of High Pressure on Proteolytic Enzymes in Cheese: Relationship with the Proteolysis of Ewe Milk Cheese
}

\author{
B. Juan, V. Ferragut, M. Buffa, B. Guamis, and A. J. Trujillo ${ }^{1}$ \\ Centre Especial de Recerca Planta de Tecnologia dels Aliments (CERPTA), CeRTA, XiT, Departament de Ciència Animal i dels Aliments, \\ Facultat de Veterinària, Universitat Autònoma de Barcelona, 08193 Bellaterra, Spain
}

\begin{abstract}
Ewe milk cheeses were submitted to 200, 300, 400, and $500 \mathrm{MPa}(2 \mathrm{P}$ to $5 \mathrm{P})$ at 2 stages of ripening (after 1 and $15 \mathrm{~d}$ of manufacturing; P1 and P15). The highpressure-treated cheeses showed a more important hydrolysis of $\beta$-casein than control and $2 \mathrm{P} 1$ cheeses. Degradation of $\alpha_{\mathrm{s} 1}$-casein was more important in 3P1, 4P1, and $\mathrm{P} 15$ cheeses than control and $2 \mathrm{P} 1$ cheeses. The $5 \mathrm{P} 1$ cheeses exhibited the lowest degradation of $\alpha_{\mathrm{s}}$-caseins, probably as a consequence of the inactivation of residual chymosin. Treatment at $300 \mathrm{MPa}$ applied on the first day of ripening increased the peptidolytic activity, accelerating the secondary proteolysis of cheeses. The 3P1 cheeses had extensive peptide degradation and the highest content of free amino acids. Treatments at 500 $\mathrm{MPa}$, however, decelerated the proteolysis of cheeses due to a reduction of microbial population and inactivation of enzymes.
\end{abstract}

Key words: high-pressure treatment, ewe milk cheese, proteolysis

\section{INTRODUCTION}

Proteolysis is the most complex and important biochemical event that occurs during ripening (Fox, 1989), and it plays a direct role on cheese flavor and texture development in most cheese varieties (Sousa et al., 2001). The rate and extent of proteolysis that occur during ripening are determined by the types and activities of the proteolytic enzymes present (i.e., residual coagulants such as chymosin, plasmin, and proteinases/ peptidases from starter and nonstarter bacteria). The chemical composition (i.e., salt, $\mathrm{pH}$, and moisture contents) of cheese also influences proteolysis. In addition, the structure of cheese and the accessibility of various cleavage sites on the caseins in the cheese matrix may determine the rate and extent of proteolysis (Wilkinson and Kilcawley, 2005).

Received November 28, 2006.

Accepted December 27, 2006.

${ }^{1}$ Corresponding author: toni.trujillo@uab.es
In cheese, the concerted action of residual coagulant, indigenous milk proteinases, and starter proteinases on paracasein (primary proteolysis) provides suitable substrates for the starter peptidases, which generate small peptides and free amino acids (FAA; secondary proteolysis; Wilkinson, 1999). However, most of the starter enzymes are located intracellularly (Tan et al., 1992), suggesting that autolysis of starter bacteria, with release of intracellular enzymes, may have an important role in cheese ripening (Fox, 1989; Crow et al., 1995). The earlier release of intracellular enzymes into the cheese matrix could increase the proteolysis of cheeses, thus accelerating the ripening processes.

A number of reports have indicated that high-pressure (HP) treatment may be used to accelerate cheese ripening, in particular proteolysis (O'Reilly et al., 2001). The HP treatment causes membrane damage and an increase in the cellular permeability (Cheftel, 1992), thus favoring the release of intracellular material such as peptidases to the medium (Trujillo et al., 2000a). On the other hand, it has been indicated that HP treatment can induce conformational changes in casein structure, making the protein more susceptible to the action of proteases (Kunugi, 1993).

The application of HP can induce changes in the main proteolytic enzymes involved in cheese ripening (i.e., residual chymosin, plasmin, and starter peptidases) as Malone et al. (2003) in solution buffers, and Trujillo et al. (2000b) and Huppertz et al. (2004) in cheese have shown. The effect of HP on cheese enzymes could influence primary and secondary proteolysis of cheeses.

The possibility of accelerating the ripening of Cheddar cheese by exposure to a treatment at $50 \mathrm{MPa}$ for 3 $\mathrm{d}$ at $25^{\circ} \mathrm{C}$ at different stages of ripening was studied by O'Reilly et al. (2000). These authors found that there was an immediate increase in $\mathrm{pH} 4.6$-soluble nitrogen (WSN) and FAA in 2-d-old cheese, although this effect decreased during ripening time. The study of primary proteolysis of cheeses assessed by urea PAGE also indicated that HP treatment accelerated degradation of $\alpha_{\mathrm{s} 1^{-}}$ casein and accumulation of $\alpha_{\mathrm{s} 1}$-I-casein.

Studies performed on HP-treated Gouda cheese (50 to $500 \mathrm{MPa}$ ) for holding times of 20 to $100 \mathrm{~min}$ or $3 \mathrm{~d}$ 
showed that HP treatment did not influence indices of proteolysis $(\mathrm{pH}$ 4.6-soluble and phosphotungstic acid nitrogens, FAA, and casein breakdown by SDS-PAGE) during ripening (Kolakowski et al., 1998; Messens et al., 1999). These results indicate that in this cheese variety proteolysis by chymosin, plasmin, and the proteinase/peptidase system of the starter bacteria were apparently not influenced by these HP treatments, although enzyme activities were not evaluated.

Hispanico cheese HP-treated at $400 \mathrm{MPa}$ for $5 \mathrm{~min}$ at $10^{\circ} \mathrm{C}$ exhibited faster caseinolysis and FAA formation than untreated cheeses (Ávila et al., 2006). Saldo et al. (2002) found twice the levels of FAA in HP-treated (400 $\mathrm{MPa}$ for $15 \mathrm{~min}$ at $14^{\circ} \mathrm{C}$ ) goat milk cheeses; however, the breakdown of $\alpha_{\mathrm{s}}$-caseins was lower in HP-treated than in control cheeses.

The objective of this study was to investigate the effects of HP treatments, applied at 2 stages of ripening, on the main proteolytic enzymes implicated in cheese ripening, and their relationship to the primary and secondary proteolysis in ewe milk cheese.

\section{MATERIALS AND METHODS}

\section{Cheese Making}

Two independent batches of semi-hard cheeses $(\sim 0.5$ $\mathrm{kg}$ ) were manufactured from pasteurized $\left(75.5^{\circ} \mathrm{C}, 1\right.$ min) ewe milk. Cheeses were produced by $1 \%$ starter culture [Lactococcus lactis ssp. lactis, Lactococcus lactis ssp. cremoris (Sacco SRL, CO, Milan, Italy)], 0.05\% (wt/ vol) of $\mathrm{CaCl}_{2}, 0.02 \%$ (vol/vol) of calf rennet (Renifor-10, $520 \mathrm{mg}$ of chymosin/L, Laboratorios Arroyo, Santander, Spain), and $0.01 \%$ of lysozyme. Temperature was held at $38^{\circ} \mathrm{C}$, and the coagulation process lasted about 30 min. The coagulum was cut into 8 - to $10-\mathrm{mm}$ cubes, and the curd was drained, molded, and pressed in a horizontal pneumatic press (Garvia S.A., Barcelona, Spain) at $1.2 \mathrm{kPa}$ for $30 \mathrm{~min}$, followed by $1.8 \mathrm{kPa}$ for $30 \mathrm{~min}$, and finally $2.45 \mathrm{kPa}$ for $60 \mathrm{~min}$. Cheeses were salted by immersion in brine $(20 \% \mathrm{NaCl}$ solution) for $2 \mathrm{~h}$ and ripened in a room at $12{ }^{\circ} \mathrm{C}$ and $85 \%$ relative humidity for $60 \mathrm{~d}$.

\section{HP Treatment}

Cheeses were packed into vacuum pouches, vacuumsealed, and pressure-treated in a batch isostatic press (GEC Alsthom ACB, Nantes, France) at 200, 300, 400, or $500 \mathrm{MPa}(\mathbf{2 P}$ to $\mathbf{5 P})$ for $10 \mathrm{~min}$ at $12^{\circ} \mathrm{C}$. One group of cheeses was treated on the first day (P1) after manufacture and the others after $15 \mathrm{~d}$ (P15) of ripening. Untreated cheeses were used as a control.

\section{Cheese Composition and Microbiological Analysis}

Gross composition of cheeses was determined in grated samples. Triplicate samples were assayed for moisture content (IDF, 1982). The $\mathrm{pH}$ was measured with a pH meter (MicropH 2001, Crison, Alella, Spain) on a cheese: distilled water (1:1) slurry. Analyses were performed at $1,15,30$, and $60 \mathrm{~d}$ after cheese making. Microbiological analyses of total counts, Enterobacteriaceae, lactococci, and lactobacilli were performed as described by Juan et al. (2004).

\section{Autolysis and Aminopeptidase Activity}

Starter autolysis was assayed $24 \mathrm{~h}$ postpressurization by determination of lactate dehydrogenase (LDH) activity as O'Reilly et al. (2002) described, and results were expressed as international units (U/g of cheese), where 1 unit was defined as the amount of enzyme that catalyzes the reduction of 1 micromole of NAD per minute.

Cheese extract for aminopeptidase activity was obtained by homogenizing $20 \mathrm{~g}$ of cheese with $30 \mathrm{~mL}$ of $0.1 \mathrm{M}$ sodium phosphate buffer $(\mathrm{pH}=7)$ at $4^{\circ} \mathrm{C}$ for 3 min in a Stomacher, followed by centrifuging $(12,000$ $\times g, 15 \mathrm{~min}, 4^{\circ} \mathrm{C}$ ) and filtering through Whatman No. 1 paper. Aminopeptidase activity was determined in duplicate on the cheese extract by using leucine- $p$-nitroanilide (Leu-p-NA) as substrate (Desmazeud and Juge, 1976), and results expressed as nanomoles of $p$-NA per hour per gram of cheese.

\section{Water-Soluble Nitrogen and Free Amino Acids}

Water-soluble extracts of the cheeses were prepared according to the method of Kuchroo and Fox (1982), and the WSN fractions were obtained from water-soluble extracts and determined by the Kjeldahl method (IDF, 1993).

Total FAA were determined on the water soluble extracts by the cadmium-ninhydrin method described by Folkertsma and Fox (1992).

\section{Residual Chymosin and Plasmin Activities}

Residual chymosin activity was determined on an extract obtained by mixing $50 \mathrm{mg}$ of cheese with 1.5 $\mathrm{mL}$ of $0.1 M$ trisodium citrate and placed in a water bath at $37^{\circ} \mathrm{C}$ for $30 \mathrm{~min}$, during which it was agitated briefly at 5-min intervals using a vortex mixer to disperse the cheese. The samples were then centrifuged at $1,000 \times g$ for $2 \mathrm{~min}$ to separate the fat. The aqueous layer was used for analysis using a synthetic heptapeptide substrate (Pro-Thr-Glu-Phe-[NO $\mathrm{NO}_{2}$-Phe]-Arg-Leu; 
Bachem AG, Bubendorf, Switzerland) and measured by HPLC as described by Hurley et al. (1999).

Residual plasmin activity was determined on a cheese extract by mixing $1 \mathrm{~g}$ of cheese with $9 \mathrm{~mL}$ of $2 \%$ (wt/vol) sterile trisodium citrate solution and placed in a water bath at $37^{\circ} \mathrm{C}$ for $15 \mathrm{~min}$, during which it was constantly agitated. The samples were then centrifuged at $1,000 \times g$ for $5 \mathrm{~min}$ at $4^{\circ} \mathrm{C}$ to remove the fat. The aqueous layer was centrifuged at 27,000 $\times g$ for $10 \mathrm{~min}$ at $4^{\circ} \mathrm{C}$. The clear extract was assayed for plasmin activity as described by Rampilli and Raja (1998). Plasmin activity was expressed as units, with 1 unit being the amount of enzyme that produced a change in absorbance at $405 \mathrm{~nm}$ of $0.1 \mathrm{in} 60 \mathrm{~min}$.

\section{Residual Caseins}

The water-insoluble fractions recovered during the water-soluble extraction were washed 3 times with 1 $M$ sodium acetate buffer ( $\mathrm{pH} 4.6$ ), and the remaining fat was eliminated by washing with dichloromethanesodium acetate buffer $(1: 1, \mathrm{vol} / \mathrm{vol})$. The final protein precipitate was then lyophilized. Capillary electrophoresis analyses were performed following the method of Recio and Olieman (1996). Separations were carried out using a Agilent CE Instrument (Agilent Technologies, Germany) controlled by Chemstation Software (Agilent). The separations were performed using a fused-silica capillary column (BGB Analytik, Essen, Germany) of $0.6 \mathrm{~m} \times 50 \mu \mathrm{m}$ i.d. (effective length 0.53 $\mathrm{m}$ ) applying voltage of $20 \mathrm{kV}$ at $45^{\circ} \mathrm{C}$ and a final current of approximately $33 \mu \mathrm{A}$. Sample injection was performed by pressure of $50 \mathrm{mb}, 4 \mathrm{~s}$. Protein components were detected at $214 \mathrm{~nm}$. The area of each peak was integrated using Agilent ChemStation Operation Software and designation of capillary electrophoresis peaks of intact caseins (para $\kappa^{-}, \alpha_{\mathrm{s} 1^{-}}, \alpha_{\mathrm{s} 2^{-}}$, and $\beta$-CN) was carried out by comparing the electrophoregrams of 1-d-old cheeses with those of isolated pure proteins (Trujillo et al., 2000c). The extent of breakdown of caseins was expressed as a relative percentage of peak areas of 1d-old cheeses.

\section{Peptides Analysis}

Peptides in the water-soluble fraction were separated by reverse-phase HPLC using an automated system (LCM1, Waters Corporation, Milford, MA). Separations were carried out on a $250-\times 4.6-\mathrm{mm}$ column packed with C18-bonded silica gel with a particle diameter of $5 \mu \mathrm{m}$ and pore width of 3,000 $\mathrm{nm}$ (Simmetry 300, Waters) at a constant temperature of $40^{\circ} \mathrm{C}$, following the method of González del Llano et al. (1995). After running the samples, the integration area of peptides, ex- cluding that of FAA, was determined. The area of peptides eluted between 10 and 35 min was considered the hydrophilic peptide area, whereas the area of peptides eluted from 35 to 80 min was considered the hydrophobic peptide area. The amounts of hydrophobic and hydrophilic peptides were expressed as units of chromatogram area to milligrams of cheese DM.

\section{Statistical Analysis}

An ANOVA was performed on all data from 2 batches obtained at each stage of ripening using SPSS Win version 13.0 (SPSS Inc., Chicago, IL). Mean comparisons were carried out using the Student-NewmanKeuls test. Level of significance was set for $P<0.05$. Principal components analysis (PCA) was carried out using Statistica Software (6.0 version, Statsoft Inc., Tulsa, OK) on enzymatic activities and proteolysis variables.

\section{RESULTS AND DISCUSSION}

\section{Microbiological Analysis}

The viability of microorganisms in cheese was significantly affected by the HP treatment (Table 1). The initial Enterobacteriaceae counts in control cheeses were $5 \log$ units, which decreased until $1 \log$ unit at 60 $\mathrm{d}$ of ripening. A reduction of $2 \mathrm{log}$ units was observed on the first day after treatments at 200 and $300 \mathrm{MPa}$. Pressures of 400 and $500 \mathrm{MPa}$ reduced 3 and $4 \mathrm{log}$ units, respectively. The total inactivation of Enterobacteriaceae became evident from $300 \mathrm{MPa}$, showing undetectable levels in $3 \mathrm{P}, 4 \mathrm{P}$, and $5 \mathrm{P}$ cheeses at $15 \mathrm{~d}$ of ripening. At this moment, $2 \mathrm{P}$ cheeses showed 1 (for $2 \mathrm{P} 1$ cheeses) and 2 (for $2 \mathrm{P} 15$ cheeses) log units less than control cheeses, after which counts declined to undetectable levels.

Initial counts of lactic acid bacteria were 9 log units, which were reduced $1 \mathrm{log}$ unit by pressures of 200 and $300 \mathrm{MPa}$, and 2 log units by $400 \mathrm{MPa}$. A drastic decrease (5 log units) was found in cheeses HP-treated at 500 $\mathrm{MPa}$. In general, at $60 \mathrm{~d}$ of ripening, the counts of lactococci in HP-treated cheeses were similar to those found in control cheeses, except in $5 \mathrm{P}$ cheeses, which showed 4 log units lower than the control.

Counts of lactobacilli on $d 1$ were 2 log units lower in 4P1 and 5P1 cheeses than in untreated cheeses. Lactobacilli populations recovered with time, and at $60 \mathrm{~d}$ of ripening, counts of cheeses HP-treated at $\leq 400 \mathrm{MPa}$ were identical ( $\mathrm{P} 15$ cheeses) or higher ( $\mathrm{P} 1$ cheeses) than those found in control cheeses. However, a significant decrease (3 and 4 log units) was observed in HP-treated cheeses at $500 \mathrm{MPa}$ at 1 and $15 \mathrm{~d}$ of ripening, respectively. For total bacteria, a progressive decrease of 
Table 1. Mean values of microbial counts (log cfu/g) of control and high-pressure (HP)-treated ewe milk cheeses during ripening

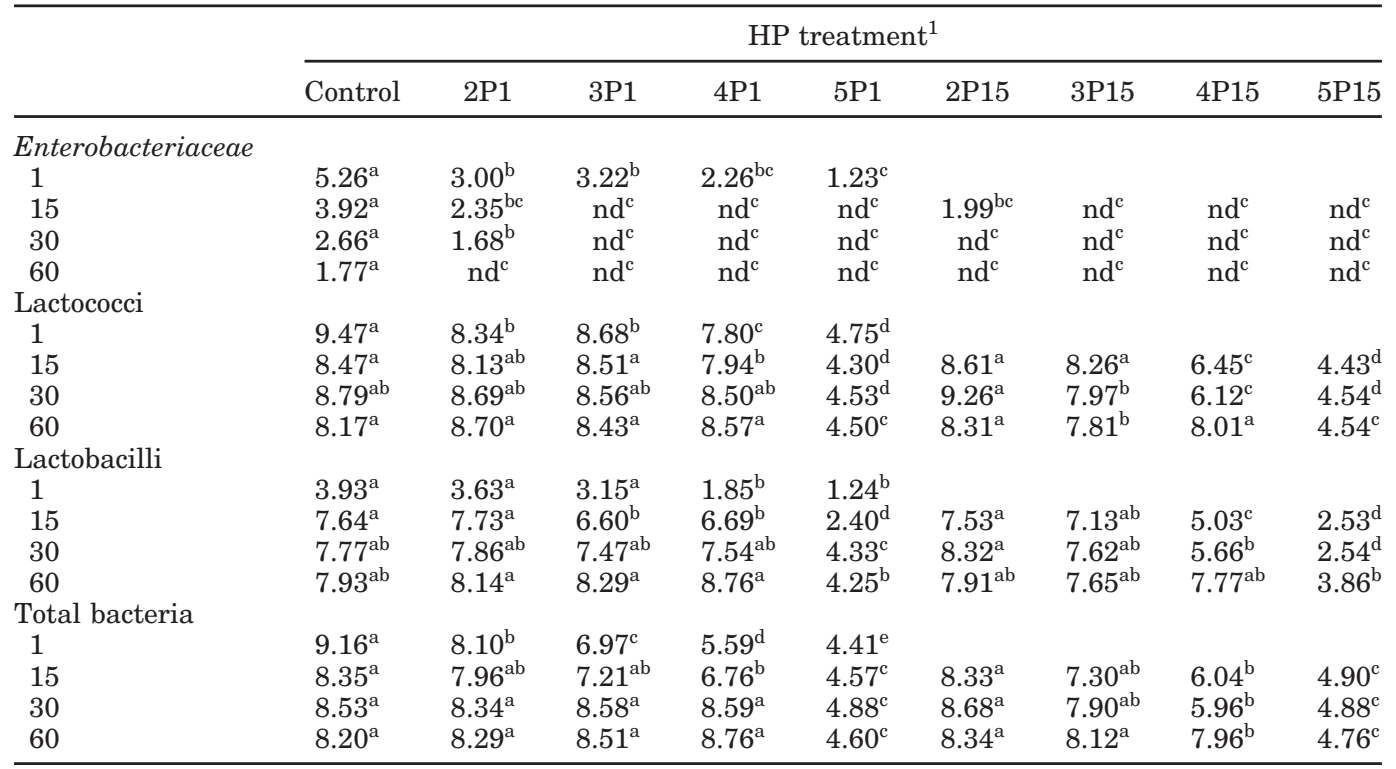

${ }^{\mathrm{a}-\mathrm{e}}$ Means within a row with different superscripts differ $(P \leq 0.05)$.

${ }^{1}$ Treatments: $2 \mathrm{P} 1,3 \mathrm{P} 1,4 \mathrm{P} 1$, and $5 \mathrm{P} 1=$ cheeses treated at 200, 300, 400, and $500 \mathrm{MPa}$, respectively, on the first day of manufacturing; $2 \mathrm{P} 15,3 \mathrm{P} 15,4 \mathrm{P} 15$, and $5 \mathrm{P} 15=$ cheeses treated at 200, 300, 400, and 500 $\mathrm{MPa}$, respectively, at $15 \mathrm{~d}$ of manufacturing. nd = below detection limit.

counts was observed on $\mathrm{d} 1$ as the pressure increased $(1,3,4$, and 5 log units for $200,300,400$, and $500 \mathrm{MPa}$, respectively). However, counts of total bacteria were recovered during ripening in cheeses HP-treated at $\leq 400 \mathrm{MPa}$, reaching similar values to control cheeses at $60 \mathrm{~d}$ of ripening (except $4 \mathrm{P} 15$ cheeses, which presented 1 $\log$ unit lower than the control). A decrease of 4 log units in the total bacteria counts was observed in cheeses HP-treated at $500 \mathrm{MPa}$. This significant decrease of microbial counts obtained at $\geq 400 \mathrm{MPa}$ agreed with previous reports in other cheese varieties (Reps et al., 1998; Wick et al., 2004).

\section{Cheese Composition}

Moisture content decreased during ripening in all cheeses (Table 2). On the first day, HP-treated cheeses presented slightly lower values of moisture content than control cheeses, probably due to the water expulsion caused by the HP treatments. Afterwards, 4P1 and 5P1 cheeses presented the highest moisture content during the entire ripening period. This could be due to HP-induced changes in the cheese protein network, lending to the formation of a new structure that retains better the water in cheeses. Similar results have been obtained in goat milk cheese (Saldo et al., 2002) and cow milk smear-ripened cheeses (Messens et al., 2000).

On the first day of ripening, the $\mathrm{pH}$ of cheeses HPtreated at $\geq 400 \mathrm{MPa}$ was significantly higher than con- trol, 2P1, and 3P1 cheeses (Table 2). An increase of $\mathrm{pH}$ after HP treatment has also been described in Gouda (Messens et al., 1999) and goat milk (Saldo et al., 2002) cheeses. This has been attributed to the release of colloidal calcium phosphate into the soluble phase due to HP treatment, which causes a disintegration of casein micelles (Messens et al., 1998). The $\mathrm{pH}$ of cheeses presented a decrease during ripening due to the degradation of residual lactose in lactic acid by lactic acid bacteria. The $\mathrm{pH}$ values of $\mathrm{P} 1$ cheeses increased with pressure and could be related to the inactivation of glycolytic enzymes (Casal and Gómez, 1999; Krasowska et al., 2005 ) and to the reduction in lactic acid bacteria caused by the pressure treatment (Table 1 ). The $5 \mathrm{P} 1$ cheeses always had the highest $\mathrm{pH}$ values. On the other hand, $\mathrm{P} 15$ cheeses showed similar $\mathrm{pH}$ behavior to control cheeses, which indicates that at $15 \mathrm{~d}$ of ripening the acidification process was finished.

\section{Autolysis and Aminopeptidase Activity}

Cell lysis was assayed postpressurization and after $60 \mathrm{~d}$ of ripening (Table 3). On the first day of ripening an increase of LDH activity was observed with the increase of pressure up to $400 \mathrm{MPa}$. At $15 \mathrm{~d}$ of ripening, 3P1 cheeses showed the highest LDH activity, whereas cheeses HP-treated at $500 \mathrm{MPa}$ had the lowest values. As has been previously reported, the activity of $\mathrm{LDH}$ appeared largely unaffected by pressure up to $400 \mathrm{MPa}$ 
Table 2. Mean values \pm SD of $\mathrm{pH}$ and moisture content of control and high-pressure (HP)-treated ewe milk cheeses during ripening

\begin{tabular}{|c|c|c|c|c|c|c|c|c|c|}
\hline \multirow[b]{2}{*}{ Item } & \multicolumn{9}{|c|}{ HP treatment ${ }^{1}$} \\
\hline & Control & $2 \mathrm{P} 1$ & $3 \mathrm{P} 1$ & $4 \mathrm{P} 1$ & $5 \mathrm{P} 1$ & 2P15 & $3 \mathrm{P} 15$ & $4 \mathrm{P} 15$ & $5 \mathrm{P} 15$ \\
\hline \multicolumn{10}{|l|}{$\mathrm{pH}$} \\
\hline 1 & $5.31 \pm 0.06^{\mathrm{b}}$ & $5.36 \pm 0.01^{b}$ & $5.35 \pm 0.01^{b}$ & $5.46^{\mathrm{a}}$ & $5.46 \pm 0.01^{\mathrm{a}}$ & & & & \\
\hline 15 & $5.02 \pm 0.01^{\mathrm{f}}$ & $5.16 \pm 0.02^{\mathrm{d}}$ & $5.31 \pm 0.01^{\mathrm{c}}$ & $5.39 \pm 0.01^{b}$ & $5.48 \pm 0.03^{\mathrm{a}}$ & $5.02 \pm 0.01^{\mathrm{f}}$ & $5.07 \pm 0.02^{\mathrm{e}}$ & $5.06 \pm 0.03^{\mathrm{e}}$ & $5.09^{\mathrm{e}}$ \\
\hline 30 & $4.99 \pm 0.06^{\mathrm{d}}$ & $5.07 \pm 0.01^{\mathrm{dc}}$ & $5.14 \pm 0.02^{b}$ & $5.18 \pm 0.01^{b}$ & $5.52 \pm 0.06^{\mathrm{a}}$ & $4.99 \pm 0.02^{\mathrm{d}}$ & $5.03 \pm 0.02^{\text {cd }}$ & $5.06 \pm 0.04^{\mathrm{cd}}$ & $5.07 \pm 0.04^{\mathrm{c}}$ \\
\hline 60 & $4.99 \pm 0.04^{\mathrm{c}}$ & $5.01 \pm 0.04^{\mathrm{c}}$ & $4.93 \pm 0.02^{\mathrm{d}}$ & $4.90 \pm 0.01^{\mathrm{d}}$ & $5.51 \pm 0.04^{\mathrm{a}}$ & $5.01 \pm 0.05^{\mathrm{c}}$ & $5.01 \pm 0.01^{\mathrm{c}}$ & $5.04 \pm 0.02^{\mathrm{c}}$ & $5.10 \pm 0.01^{\mathrm{b}}$ \\
\hline \multicolumn{10}{|c|}{ Moisture (\%) } \\
\hline 1 & $44.75 \pm 0.16^{\mathrm{a}}$ & $43.42 \pm 0.21^{b}$ & $44.30 \pm 0.64^{\mathrm{ab}}$ & $43.91 \pm 0.52^{\mathrm{ab}}$ & $44.10 \pm 0.61^{\mathrm{ab}}$ & & & & \\
\hline 15 & $40.12 \pm 0.24^{\mathrm{cd}}$ & $38.38 \pm 0.32^{\mathrm{e}}$ & $39.85 \pm 0.38^{\mathrm{cd}}$ & $41.53 \pm 0.58^{\mathrm{b}}$ & $42.38 \pm 0.18^{\mathrm{a}}$ & $40.07 \pm 0.13^{\text {cd }}$ & $40.01 \pm 0.45^{\mathrm{cd}}$ & $40.80 \pm 0.69^{c}$ & $39.64 \pm 0.66^{\mathrm{d}}$ \\
\hline 30 & $36.14 \pm 0.43^{\mathrm{c}}$ & $34.93 \pm 0.70^{\mathrm{d}}$ & $34.88 \pm 0.46^{\mathrm{d}}$ & $38.61 \pm 0.66^{\mathrm{a}}$ & $39.44 \pm 0.47^{\mathrm{a}}$ & $36.57 \pm 0.68^{\mathrm{c}}$ & $36.57 \pm 1.59^{\mathrm{b}}$ & $35.95 \pm 0.26^{\text {cd }}$ & $36.17 \pm 0.87^{\mathrm{c}}$ \\
\hline 60 & $31.29 \pm 1.18^{\mathrm{b}}$ & $30.21 \pm 0.87^{\mathrm{c}}$ & $30.87 \pm 0.62^{\mathrm{bc}}$ & $32.63 \pm 0.29^{\mathrm{a}}$ & $32.64 \pm 0.8^{\mathrm{a}}$ & $31.31 \pm 0.24^{\mathrm{b}}$ & $31.87 \pm 0.16^{\mathrm{ab}}$ & $31.79 \pm 0.89^{\mathrm{ab}}$ & $31.52 \pm 0.29^{\mathrm{ab}}$ \\
\hline
\end{tabular}

${ }^{\mathrm{a}-\mathrm{f}}$ Means for the same parameter and day of ripening with different superscripts differ $(P \leq 0.05)$.

${ }^{1}$ Treatments: $2 \mathrm{P} 1,3 \mathrm{P} 1,4 \mathrm{P} 1$, and $5 \mathrm{P} 1$ = cheeses treated at $200,300,400$, and $500 \mathrm{MPa}$, respectively, on the first day of manufacturing; $2 \mathrm{P} 15$, $3 \mathrm{P} 15$, $4 \mathrm{P} 15$, and $5 \mathrm{P} 15=$ cheeses treated at 200, 300, 400, and $500 \mathrm{MPa}$, respectively, at $15 \mathrm{~d}$ of manufacturing.

Table 3. Mean values \pm SD of lactate dehydrogenase (LDH) activities (U/g) and aminopeptidase activity (nmol of $p$-NA/g per h) of control and high-pressure (HP)-treated ewe milk cheeses during ripening

\begin{tabular}{|c|c|c|c|c|c|c|c|c|c|c|}
\hline \multirow[b]{2}{*}{ Item } & \multicolumn{10}{|c|}{ HP treatment ${ }^{1}$} \\
\hline & Control & $2 \mathrm{P} 1$ & $3 \mathrm{P} 1$ & & $4 \mathrm{P} 1$ & $5 \mathrm{P} 1$ & $2 \mathrm{P} 15$ & $3 \mathrm{P} 15$ & $4 \mathrm{P} 15$ & $5 \mathrm{P} 15$ \\
\hline \multicolumn{11}{|l|}{ LDH } \\
\hline 1 & $28.62 \pm 6.45^{\mathrm{d}}$ & $60.85 \pm 16.2^{\mathrm{c}}$ & $77.97 \pm 13.09^{b}$ & 87.38 & $\pm 9.34^{\mathrm{a}}$ & $50.64 \pm 9.02^{\mathrm{c}}$ & & & & \\
\hline 15 & $140.83 \pm 54.28^{\mathrm{bc}}$ & $196.78 \pm 53.85^{\mathrm{ab}}$ & $263.34 \pm 123^{\mathrm{a}}$ & 111.06 & $\pm 22.29^{b}$ & $78.77 \pm 7.26^{\mathrm{c}}$ & $86.81 \pm 27.06^{\mathrm{c}}$ & $89.71 \pm 36.18^{\mathrm{c}}$ & $74.27 \pm 15.09^{\mathrm{c}}$ & $59.48 \pm 26.53^{\mathrm{c}}$ \\
\hline 60 & $393.57 \pm 5.08^{\mathrm{bc}}$ & $422.83 \pm 22.96^{\mathrm{ab}}$ & $356.67 \pm 20.12^{\mathrm{cd}}$ & 351.12 & $\pm 14.32^{\mathrm{cd}}$ & $218.49 \pm 8.87^{\mathrm{e}}$ & $445.42 \pm 17.39^{\mathrm{a}}$ & $428.54 \pm 6.48^{\mathrm{ab}}$ & $362.94 \pm 13.98^{\mathrm{cd}}$ & $324.11 \pm 12.96^{\mathrm{d}}$ \\
\hline \multicolumn{11}{|c|}{ Aminopeptidase } \\
\hline 1 & $0.49 \pm 0.11^{\mathrm{a}}$ & $0.44 \pm 0.02^{\mathrm{ab}}$ & $0.21 \pm 0.01^{\mathrm{c}}$ & 0.30 & $\pm 0.09^{b c}$ & $0.35 \pm 0.10^{\mathrm{abc}}$ & & & & \\
\hline 15 & $1.35 \pm 0.21^{\mathrm{d}}$ & $2.18 \pm 0.05^{\mathrm{abc}}$ & $2.43 \pm 0.18^{\mathrm{a}}$ & 1.77 & $\pm 0.21^{\mathrm{c}}$ & $2.09 \pm 0.33^{\mathrm{abc}}$ & $2.31 \pm 0.51^{\mathrm{ab}}$ & $2.51 \pm 0.15^{\mathrm{a}}$ & $1.84 \pm 0.11^{\mathrm{bc}}$ & $1.03 \pm 0.23^{\mathrm{d}}$ \\
\hline 30 & $2.39 \pm 0.95^{\mathrm{c}}$ & $3.78 \pm 0.72^{\mathrm{ab}}$ & $4.85 \pm 0.64^{\mathrm{a}}$ & 4.82 & $\pm 0.59^{a}$ & $2.74 \pm 0.81^{\mathrm{cd}}$ & $4.86 \pm 1.04^{\mathrm{a}}$ & $4.93 \pm 0.65^{\mathrm{a}}$ & $3.61 \pm 1.13^{\mathrm{ab}}$ & $1.42 \pm 0.44^{\mathrm{d}}$ \\
\hline 60 & $3.57 \pm 0.59^{\mathrm{c}}$ & $5.76 \pm 0.50^{\mathrm{b}}$ & $8.03 \pm 0.58^{\mathrm{a}}$ & 7.89 & $\pm 0.17^{\mathrm{a}}$ & $6.38 \pm 0.37^{\mathrm{b}}$ & $6.15 \pm 0.21^{\mathrm{b}}$ & $5.95 \pm 1.01^{\mathrm{b}}$ & $6.09 \pm 0.21^{\mathrm{b}}$ & $2.19 \pm 0.24^{\mathrm{d}}$ \\
\hline
\end{tabular}

${ }^{a-e}$ Means for the same parameter and day of ripening with different superscripts differ $(P \leq 0.05)$

${ }^{1}$ Treatments: $2 \mathrm{P} 1,3 \mathrm{P} 1,4 \mathrm{P} 1$, and $5 \mathrm{P} 1=$ cheeses treated at $200,300,400$, and $500 \mathrm{MPa}$, respectively, on the first day of manufacturing; $2 \mathrm{P} 15$, $3 \mathrm{P} 15$, 4P15, and $5 \mathrm{P} 15=$ cheeses treated at $200,300,400$, and $500 \mathrm{MPa}$, respectively, at $15 \mathrm{~d}$ of manufacturing. 
when treated in cheese and cheese extracts, indicating that LDH could be used as an index of HP-induced autolysis (O'Reilly et al., 2002). However, HP treatments at $500 \mathrm{MPa}$ produced a great decrease of $\mathrm{LDH}$ activity when treated in cheese and cheese extracts, suggesting that severe HP treatments induce LDH inactivation (Juan et al., 2004), which could explain the lower $\mathrm{LDH}$ activities obtained in $5 \mathrm{P}$ cheeses. Malone et al. (2002) established that HP-induced cell lysis is pressure- and strain-dependent. Pressurizing cell suspensions of Lactococcus lactis ssp. cremoris MG1363, Malone et al. (2002) found that samples treated at 300 MPa lysed significantly more than those treated at 100 , 200 , and 600 to $800 \mathrm{MPa}$.

Aminopeptidase activity increased as cheese aged in all cheeses (Table 3 ). At the first day of ripening, aminopeptidase activity in HP-treated cheeses were lower than the activity recorded in control cheeses, but afterward, HP-treated cheeses (with the exception of 5P15 cheeses) presented higher aminopeptidase activity than untreated cheeses. The HP treatment increases cell membrane permeability (Cheftel, 1992), favoring the release of endocellular material, such as peptidases, to the medium (Trujillo et al., 2000a). At $15 \mathrm{~d}$ of ripening, $3 \mathrm{P}$ cheeses showed the highest aminopeptidase activity values, and at $60 \mathrm{~d}$ of ripening the highest activity was found in $3 \mathrm{P} 1$ cheeses. The lower aminopeptidases activities were obtained in 5P15 cheeses, suggesting inactivation of aminopeptidase under these HP conditions. According to Reps et al. $(1998,2003)$ aminopeptidases activity was entirely inactivated under pressure of $600 \mathrm{MPa}$ in different cheese varieties HP-treated in 3 cycles of $5 \mathrm{~min}$. Peptidase activities of cell-free extracts of some strains of Lactococcus lactis and Lactobacillus casei were not negatively affected by pressures up to $300 \mathrm{MPa}$; nevertheless, $400 \mathrm{MPa}$ decreased peptidases activities of lactobacilli, whereas those of lactococci were unaffected (Casal and Gómez, 1999). On the other hand, the pressure treatment of $500 \mathrm{MPa}$ for 15 min exerted diversified effects on the activity of peptidases of selected strains of lactic acid bacteria (Krasowska et al., 2005). These results indicate that pressure treatment has different effects on different peptidolytic enzymes as a consequence of pressure time, pressurization medium, and bacterial species; hence, it is necessary to study peptidase activity in each medium and pressure conditions applied.

\section{Rennet and Plasmin Activities}

Residual coagulant and plasmin activities are important for proteolysis in cheese because both contribute to the primary hydrolysis of caseins. Residual chymosin is believed to be responsible for the initial soften- ing of cheese through hydrolysis of the $\mathrm{Phe}_{23}-\mathrm{Phe}_{24}$ bond of $\alpha_{\mathrm{s} 1}$-casein yielding $\alpha_{\mathrm{s} 1}$-I-casein (Creamer et al., 1982).

The HP treatment $\geq 400 \mathrm{MPa}$ applied on the first day of ripening drastically reduced the chymosin activity in ewe milk cheeses (Table 4). A reduction of 62 and $84 \%$ of the chymosin activity, compared with control cheese, was observed at $15 \mathrm{~d}$ of ripening in $4 \mathrm{P} 1$ and $5 \mathrm{P} 1$ cheeses, respectively. These results agree with those of Saldo et al. (2002) who found a reduction in the residual coagulant activity to about half of the initial value in goat milk cheese treated at $400 \mathrm{MPa}$ for 5 min on the first day of ripening. On the other hand, the chymosin activity was not influenced by pressure treatment (50 to $400 \mathrm{MPa}, 20$ to $100 \mathrm{~min}$ ) in Gouda cheese (Messens et al., 1999), and it appeared to be unaffected by HP treatment on Cheddar cheese pressurized at 100 to 400 $\mathrm{MPa}$ (O'Reilly et al., 2002; Huppertz et al., 2004). However, pressures $\geq 600 \mathrm{MPa}$ for 15 to $60 \mathrm{~min}$ reduced to about $90 \%$ the chymosin activity in Cheddar cheese (Huppertz et al., 2004). In diluted rennet, the chymosin activity was not affected from 100 to $400 \mathrm{MPa}$; however, a reduction in their activity was observed with pressures $>400 \mathrm{MPa}$ (Trujillo et al., 2000b; Malone et al., 2003).

Plasmin is the most important of the indigenous milk proteinases and readily hydrolyzes $\beta$-casein and $\alpha_{\mathrm{s} 2^{-}}$ casein, and more slowly, $\alpha_{\mathrm{s} 1}$-casein (Fox and McSweeney, 1996). Plasmin activity decreases in milk when treated at pressures $\geq 400 \mathrm{MPa}$; nevertheless, plasmin is relatively barostable in buffer and cheese (Scollard et al., 2000). Plasmin activity was not affected significantly by any pressure treatment assayed (Table 4); results that agree with Saldo et al. (2002), who did not find differences in plasmin activity in goat milk cheeses HP-treated at $50 \mathrm{MPa}$ for $72 \mathrm{~h}$ and at $400 \mathrm{MPa}$ for $5 \mathrm{~min}$. However, a treatment of 15 to $60 \mathrm{~min}$ at 600 to $800 \mathrm{MPa}$ reduced the plamin activity by approximately $15 \%$ in Cheddar cheese (Huppertz et al., 2004).

\section{Primary Proteolysis}

Primary proteolysis in cheese may be defined as those changes in caseins and peptides, which can be detected by electrophoretic methods (Fox, 1989) and is mainly the result of the action of indigenous proteinases and the residual coagulant. However, proteinases from starter lactic acid bacteria and nonstarter microorganisms are also active in the degradation of cheese proteins (Fox et al., 1993).

In control cheeses, levels of the residual $\alpha_{\mathrm{s}}$-caseins declined considerably during ripening, whereas $\beta$-casein was scarcely degraded, with 36,54 , and $92 \%$ of $\alpha_{\mathrm{s} 1^{-}}, \alpha_{\mathrm{s} 2^{-}}$, and $\beta$-caseins intact at $60 \mathrm{~d}$ of ripening, respectively (Table 5). This low degree of breakdown of $\beta$ - 
Table 4. Mean values \pm SD of residual coagulant and plasmin activity in high-pressure (HP)-treated ewe milk cheeses

\begin{tabular}{|c|c|c|c|c|c|c|c|c|c|}
\hline \multirow[b]{2}{*}{ Item } & \multicolumn{9}{|c|}{ HP treatment ${ }^{1}$} \\
\hline & Control & $2 \mathrm{P} 1$ & $3 \mathrm{P} 1$ & $4 \mathrm{P} 1$ & $5 \mathrm{P} 1$ & $2 \mathrm{P} 15$ & $3 \mathrm{P} 15$ & $4 \mathrm{P} 15$ & $5 \mathrm{P} 15$ \\
\hline \multicolumn{10}{|c|}{ Chymosin $^{2}$} \\
\hline 1 & $142.4 \pm 36.5$ & $145.9 \pm 42.9$ & $151.2 \pm 35.1$ & $93.9 \pm 21.9^{b}$ & $29.3 \pm 15.3^{\mathrm{c}}$ & & & & \\
\hline 15 & $146.8 \pm 50.3^{\mathrm{a}}$ & $117.7 \pm 27.2^{\mathrm{ab}}$ & $99.4 \pm 49.8^{\mathrm{b}}$ & $65.5 \pm 23^{\mathrm{c}}$ & $28.13 \pm 26.1^{\mathrm{d}}$ & $128.1 \pm 21.2^{\mathrm{ab}}$ & $134.6 \pm 25.4^{\mathrm{ab}}$ & $128.6 \pm 19.6^{\mathrm{ab}}$ & $106.8 \pm 19.4^{\mathrm{ab}}$ \\
\hline \multicolumn{10}{|c|}{ Plasmin (U/g) } \\
\hline 1 & $15.85 \pm 5.34$ & $13.08 \pm 3.37$ & $16.55 \pm 4.27$ & $15.16 \pm 2.66$ & $12.57 \pm 3.96$ & & & & \\
\hline 15 & $30.32 \pm 4.55$ & $25.77 \pm 1.59$ & $27.2 \pm 4.31$ & $26.04 \pm 3.26$ & $26.62 \pm 0.95$ & $27.89 \pm 3.22$ & $27.31 \pm 3.17$ & $30.79 \pm 6.64$ & $32.64 \pm 5.99$ \\
\hline
\end{tabular}

${ }^{\mathrm{a}-\mathrm{d}}$ Means for the same parameter and day of ripening with different superscripts differ $(P \leq 0.05)$.

${ }^{1}$ Treatments: $2 \mathrm{P} 1,3 \mathrm{P} 1,4 \mathrm{P} 1$, and $5 \mathrm{P} 1=$ cheeses treated at $200,300,400$, and $500 \mathrm{MPa}$, respectively, on the first day of manufacturing; $2 \mathrm{P} 15$, $3 \mathrm{P} 15$, $4 \mathrm{P} 15$, and $5 \mathrm{P} 15=$ cheeses treated at $200,300,400$, and $500 \mathrm{MPa}$, respectively, at $15 \mathrm{~d}$ of manufacturing.

${ }^{2}$ Peak area (arbitrary units $\times 10^{3}$ ).

Table 5. Mean values \pm SD of residual caseins (expressed as a percentage of the amount in the corresponding 1-d-old cheeses) in control and high-pressure (HP)-treated ewe milk cheeses during ripening

\begin{tabular}{|c|c|c|c|c|c|c|c|c|c|}
\hline \multirow[b]{2}{*}{ Item } & \multicolumn{9}{|c|}{ HP treatment ${ }^{1}$} \\
\hline & Control & $2 \mathrm{P} 1$ & 3P1 & $4 \mathrm{P} 1$ & $5 \mathrm{P} 1$ & 2P15 & 3P15 & 4P15 & $5 \mathrm{P} 15$ \\
\hline \multicolumn{10}{|c|}{$\alpha_{\mathrm{s} 1}$-casein $(\%)$} \\
\hline 15 & $66.03 \pm 0.31^{\mathrm{bc}}$ & $61.15 \pm 7.85^{\mathrm{c}}$ & $86.68 \pm 14.94^{\mathrm{ab}}$ & $83.01 \pm 8.78^{\mathrm{ab}}$ & $99.05 \pm 3.80^{\mathrm{a}}$ & $69 \pm 2.58^{\mathrm{bc}}$ & $57.92 \pm 6.87^{\mathrm{c}}$ & $50.63 \pm 2.25^{\mathrm{c}}$ & $48.07 \pm 0.41^{\mathrm{c}}$ \\
\hline 60 & $36.29 \pm 6.13^{\mathrm{b}}$ & $40.74 \pm 9.20^{\mathrm{b}}$ & $24.78 \pm 2.80^{\mathrm{c}}$ & $20.75 \pm 4.93^{\mathrm{c}}$ & $80.04 \pm 12.15^{\mathrm{a}}$ & $23.28 \pm 3.35^{\mathrm{c}}$ & $20.77 \pm 0.52^{\mathrm{c}}$ & $21.06 \pm 2.38^{\mathrm{c}}$ & $24.49 \pm 1.70^{\mathrm{c}}$ \\
\hline \multicolumn{10}{|c|}{$\alpha_{\mathrm{s} 2}$-casein $(\%)$} \\
\hline 15 & $74.04 \pm 19.6^{\mathrm{ab}}$ & $83.58 \pm 23.7^{\mathrm{a}}$ & $75.99 \pm 6.25^{\mathrm{ab}}$ & $82.71 \pm 2.38^{\mathrm{a}}$ & $80.72 \pm 16.9^{\mathrm{a}}$ & $47.62 \pm 1.96^{\mathrm{b}}$ & $49.43 \pm 4.41^{\mathrm{b}}$ & $52.43 \pm 7.46^{\mathrm{b}}$ & $46.27 \pm 6.46^{\mathrm{b}}$ \\
\hline 60 & $53.93 \pm 9.89^{\mathrm{a}}$ & $47.30 \pm 11.46^{\mathrm{ab}}$ & $35.42 \pm 4.97^{\mathrm{ab}}$ & $39.23 \pm 8.05^{\mathrm{ab}}$ & $42.19 \pm 5.71^{\mathrm{ab}}$ & $43.05 \pm 4.06^{\mathrm{ab}}$ & $41.42 \pm 8.8^{\mathrm{ab}}$ & $41.55 \pm 10.9^{\mathrm{ab}}$ & $33.07 \pm 3.68^{b}$ \\
\hline \multicolumn{10}{|c|}{$\alpha_{\mathrm{s} 1}$-I-casein $(\%)$} \\
\hline 15 & $52 \pm 2.8^{\mathrm{a}}$ & $48.7 \pm 3.1^{\mathrm{ab}}$ & $34.1 \pm 0.7^{\mathrm{c}}$ & $34.5 \pm 0.7^{\mathrm{c}}$ & $32.5 \pm 0.7^{\mathrm{c}}$ & $48.3 \pm 5.1^{\mathrm{ab}}$ & $54.3 \pm 6.1^{\mathrm{a}}$ & $41.2 \pm 0.2^{\mathrm{bc}}$ & $38.5 \pm 0.7^{\mathrm{c}}$ \\
\hline 60 & $286.5 \pm 17.9^{\mathrm{a}}$ & $240.4 \pm 57.8^{\mathrm{a}}$ & $217.3 \pm 5.1^{\mathrm{ab}}$ & $288.8 \pm 8.3^{\mathrm{a}}$ & $123.6 \pm 13^{\mathrm{b}}$ & $210.3 \pm 49^{\mathrm{ab}}$ & $267.4 \pm 38^{\mathrm{a}}$ & $258.7 \pm 20^{\mathrm{a}}$ & $191.3 \pm 25^{\mathrm{ab}}$ \\
\hline \multicolumn{10}{|c|}{$\beta$-casein $(\%)$} \\
\hline 15 & $99.8 \pm 2.71^{\mathrm{a}}$ & $97.07 \pm 3.06^{\mathrm{a}}$ & $82.49 \pm 6.66^{\mathrm{bc}}$ & $82.09 \pm 0.94^{\mathrm{bc}}$ & $78.75 \pm 2.14^{\mathrm{c}}$ & $89.86 \pm 1.23^{b}$ & $86.52 \pm 0.86^{\mathrm{bc}}$ & $83.19 \pm 2.42^{\mathrm{bc}}$ & $77.16 \pm 0.45^{\mathrm{c}}$ \\
\hline 60 & $92.44 \pm 0.30^{\mathrm{a}}$ & $92.99 \pm 6.70^{\mathrm{a}}$ & $72.88 \pm 1.82^{\mathrm{bc}}$ & $65.33 \pm 0.21^{\mathrm{cd}}$ & $77.47 \pm 1.82^{\mathrm{b}}$ & $63.70 \pm 4.06^{\mathrm{d}}$ & $74.56 \pm 0.79^{\mathrm{b}}$ & $75.27 \pm 2.39^{\mathrm{b}}$ & $68.97 \pm 0.68^{\mathrm{bcd}}$ \\
\hline \multicolumn{10}{|c|}{ Para- $\kappa$-casein $(\%)$} \\
\hline 15 & $79.4 \pm 2.1^{\mathrm{b}}$ & $79.3 \pm 3.2^{\mathrm{b}}$ & $65.6 \pm 4.5^{\mathrm{b}}$ & $74.3 \pm 3.2^{\mathrm{b}}$ & $119.5 \pm 5.3^{\mathrm{a}}$ & $74.2 \pm 2.4^{\mathrm{b}}$ & $70.7 \pm 3.1^{\mathrm{b}}$ & $73.3 \pm 1.6^{\mathrm{b}}$ & $68.2 \pm 4.4^{\mathrm{b}}$ \\
\hline 60 & $15.7 \pm 1^{\mathrm{b}}$ & $16.7 \pm 1.1^{\mathrm{b}}$ & $12.5 \pm 1^{\mathrm{b}}$ & $11.5 \pm 0.8^{\mathrm{b}}$ & $27.4 \pm 7.2^{\mathrm{a}}$ & $13.9 \pm 3.8^{\mathrm{b}}$ & $13.2 \pm 4.1^{\mathrm{b}}$ & $16.1 \pm 3.9^{\mathrm{b}}$ & $11.9 \pm 5.6^{\mathrm{b}}$ \\
\hline
\end{tabular}

${ }^{\mathrm{a}-\mathrm{d}}$ Means for the same parameter and day of ripening with different superscripts differ $(P \leq 0.05)$.

${ }^{1}$ Treatments: $2 \mathrm{P} 1,3 \mathrm{P} 1,4 \mathrm{P} 1$, and $5 \mathrm{P} 1$ = cheeses treated at 200, 300, 400, and $500 \mathrm{MPa}$, respectively, on the first day of manufacturing; $2 \mathrm{P} 15$, 3P15, 4P15, and 5P15 = cheeses treated at $200,300,400$, and $500 \mathrm{MPa}$, respectively, at $15 \mathrm{~d}$ of manufacturing. 
casein is typical for ewe milk cheeses, in which $\beta$-casein is very resistant to proteolysis (Marcos et al., 1978).

Hydrolysis of caseins was affected significantly by the pressure treatment. At $15 \mathrm{~d}$ of ripening, $\mathrm{P} 1$ cheeses treated at $\geq 300 \mathrm{MPa}$ presented higher levels of residual $\alpha_{\mathrm{s} 1}$-caseins than untreated cheeses, whereas $\mathrm{P} 15$ cheeses had similar or lower intact $\alpha_{\mathrm{s} 1}$-casein than the control. At $60 \mathrm{~d}$ of ripening, 3P1, 4P1, and $\mathrm{P} 15$ cheeses showed higher hydrolysis of $\alpha_{\mathrm{s} 1}$-caseins than control cheeses. In contrast, 5P1 cheeses showed the highest intact $\alpha_{\mathrm{s} 1}$-casein related to the lower level of $\alpha_{\mathrm{s} 1}$-I-casein (primary degradation product of $\alpha_{\mathrm{s} 1}$-casein) detected in 5P1 cheeses (Table 5). Hydrolysis of $\alpha_{\mathrm{s} 1 \text {-casein is due }}$ mainly to the residual chymosin retained in the curd. As we have previously described, HP induced inactivation of chymosin at a pressure $\geq 400 \mathrm{MPa}$, and it was largely reduced in 5P1 cheeses (Table 4), which could explain the lower degradation of $\alpha_{\mathrm{s} 1 \text {-caseins found in }}$ these cheeses. O'Reilly et al. (2003) showed that the application of relatively low pressures (50 to $100 \mathrm{MPa}$ ) in Cheddar cheese increased degradation of $\alpha_{\mathrm{s} 1}$-casein and accumulation of $\alpha_{\mathrm{s} 1}$-I-casein. However, at higher pressures, increased breakdown of $\alpha_{\mathrm{s} 1}$-caseins was not apparent, and at 350 to $400 \mathrm{MPa}$ the accumulation of $\alpha_{\mathrm{s} 1}$-I-casein was reduced. These authors suggested that the increase in primary proteolysis in cheese may be due to conformational changes in casein structure postpressurization, making the protein more susceptible to the action of proteases.

The $\alpha_{\mathrm{s} 2}$-casein appears to be relatively resistant to proteolysis by the chymosin action, but it is susceptible to plasmin attack (Fox et al., 1993). The $\alpha_{\mathrm{s} 2}$-casein gradually decreased during ripening, and HP-treated cheeses showed higher degradation of $\alpha_{\mathrm{s} 2}$-casein than control cheeses at $60 \mathrm{~d}$ of ripening.

The $\beta$-casein was hydrolyzed to a lesser extent than $\alpha_{\mathrm{S}}$-caseins in all cheeses, except in 5P1 cheeses, which exhibited a poor $\alpha_{\mathrm{s}}$-casein hydrolysis due to the effect of HP on the chymosin activity (Table 5). Higher $\beta$ casein hydrolysis was observed in HP-treated cheeses than in control cheeses, except 2P1 cheeses, which showed similar levels to the untreated cheeses. It is known that $\beta$-casein is very susceptible to plasmin attacks and to a lesser extent to chymosin action (Fox et al., 1993). The HP did not change the activity of plasmin at any treatment conditions assayed (Table 4), but it could improve the proteolytic action of this enzyme against the $\beta$-casein (i.e., changing protein conformations), explaining the higher $\beta$-casein hydrolysis in $\mathrm{HP}$ treated cheeses. Messens et al. (1998) observed the acceleration of the hydrolysis of $\beta$-casein by plasmin in HP-treated (300 MPa) Gouda cheese, a fact that they attributed to conformational changes in the paracasein gel structure produced by pressure, which led to the exposure of susceptible peptide bonds from $\beta$-casein, which are readily cleavable by plasmin. An increase in breakdown products from plasmin activity was also found by Saldo et al. (2002) in HP-treated (400 MPa, 5 min) goat milk cheese with nonsignificant differences in plasmin activity and explained by the higher $\mathrm{pH}$ found in HP-treated cheeses, which could favor the plasmin action.

Para- $\kappa$-casein decreased during ripening in all cheeses, and significant differences were only found in $5 \mathrm{P} 1$-cheeses, where the para- $\kappa$-casein decreased at the lowest rate.

\section{Secondary Proteolysis}

Secondary proteolysis is attributed to the proteinases and peptidases of the cheese microorganisms, which degrade large-medium casein peptides to low molecular weight peptides and free amino acids.

The WSN is produced mainly by rennet and, to a lesser extent, by plasmin (McSweeney and Fox, 1997) or cell envelope proteinases from the starter (Sousa et al., 2001). Levels of WSN, expressed as percentage of total $\mathrm{N}$, increased during ripening in all cheeses (Table 6 ), and at $15 \mathrm{~d}$ of ripening, the highest amount of WSN was found in 3P15 cheeses. The WSN was influenced by the moment that the HP treatment was applied; P15 cheeses had higher values of WSN than P1 cheeses at 30 and $60 \mathrm{~d}$ of ripening. However, no significant differences were found between P15 cheeses and control cheeses at $60 \mathrm{~d}$ of ripening. In Gouda cheese, a slight increase in WSN was observed at $400 \mathrm{MPa}$ after pressure treatment; however, no significant differences in the WSN level were observed between HP and unpressurized cheese samples at longer ripening times (Messens et al., 1999). O'Reilly et al. (2003) found a greater increase in the levels of WSN by HP treatments in Cheddar cheese, which increased with pressurization time did.

Levels of hydrophobic and hydrophilic peptides decreased with the HP treatment, and the lowest values of both variables were found in $5 \mathrm{P} 1$ cheeses as a result of the lowest degree of proteolysis developed in these cheeses (Table 7). On the other hand, 5P1 cheeses exhibited the highest ratio of hydrophobic to hydrophilic peptides, which is associated with cheese bitterness. In contrast, the lowest levels of the ratio of hydrophobic to hydrophilic peptides were found in 3P1 cheeses, which also showed lower levels of hydrophobic peptides than control and the other HP-treated cheeses, and this could be beneficial for flavor quality. In this case, the lower levels of hydrophobic peptides could be associated to a higher peptidolytic activity, which agreed with the highest LDH and aminopeptidase activities (Table 3) 
Table 6. Mean values \pm SD of water-soluble nitrogen (WSN) and free amino acids (FAA; mg of Leu/g) in control and high-pressure (HP)-treated ewe milk cheeses during ripening

\begin{tabular}{|c|c|c|c|c|c|c|c|c|c|}
\hline \multirow[b]{2}{*}{ Item } & \multicolumn{9}{|c|}{ HP treatment ${ }^{1}$} \\
\hline & Control & $2 \mathrm{P} 1$ & $3 \mathrm{P} 1$ & $4 \mathrm{P} 1$ & $5 \mathrm{P} 1$ & $2 \mathrm{P} 15$ & $3 \mathrm{P} 15$ & $4 \mathrm{P} 15$ & $5 \mathrm{P} 15$ \\
\hline \multicolumn{10}{|c|}{ WSN (\% of total N) } \\
\hline 1 & $4.62 \pm 0.41$ & $4.22 \pm 0.55$ & $4.78 \pm 0.25$ & $4.56 \pm 0.61$ & $4.58 \pm 0.44$ & & & & \\
\hline 15 & $10.60 \pm 0.29^{b}$ & $10.57 \pm 1.11^{\mathrm{b}}$ & $10.22 \pm 0.11^{\mathrm{b}}$ & $10.05 \pm 0.46^{\mathrm{b}}$ & $8.23 \pm 0.19^{c}$ & $10.53 \pm 0.54^{\mathrm{b}}$ & $11.67 \pm 0.59^{\mathrm{a}}$ & $10.89 \pm 0.25^{\mathrm{b}}$ & $10.64 \pm 0.30^{\mathrm{b}}$ \\
\hline 30 & $12.35 \pm 0.38^{\mathrm{b}}$ & $11.58 \pm 0.61^{\mathrm{bc}}$ & $12.42 \pm 1.06^{\mathrm{b}}$ & $11.68 \pm 0.46^{\mathrm{bc}}$ & $10.29 \pm 0.59^{\mathrm{bc}}$ & $11.81 \pm 1.57^{\mathrm{d}}$ & $15.37 \pm 1.87^{\mathrm{a}}$ & $14.61 \pm 0.90^{\mathrm{a}}$ & $14.41 \pm 1.43^{\mathrm{a}}$ \\
\hline 60 & $16.78 \pm 0.79^{\mathrm{a}}$ & $15.09 \pm 0.51^{\mathrm{b}}$ & $15.22 \pm 0.79^{b}$ & $14.91 \pm 0.93^{\mathrm{b}}$ & $12.58 \pm 0.83^{\mathrm{c}}$ & $17.32 \pm 0.60^{\mathrm{a}}$ & $16.94 \pm 0.64^{\mathrm{a}}$ & $17.71 \pm 0.83^{\mathrm{a}}$ & $17.35 \pm 0.56^{\mathrm{a}}$ \\
\hline \multicolumn{10}{|l|}{ FAA } \\
\hline 1 & $0.18 \pm 0.02^{\mathrm{a}}$ & $0.16 \pm 0.02^{\mathrm{b}}$ & $0.16 \pm 0.004^{\mathrm{b}}$ & $0.01 \pm 0.01^{\mathrm{c}}$ & $0.01 \pm 0.005^{\mathrm{d}}$ & & & & \\
\hline 15 & $0.76 \pm 0.20^{\mathrm{bc}}$ & $0.91 \pm 0.22^{\mathrm{ab}}$ & $1.01 \pm 0.19^{\mathrm{a}}$ & $0.66 \pm 0.12^{\mathrm{c}}$ & $0.30 \pm 0.06^{\mathrm{d}}$ & $0.91 \pm 0.03^{\mathrm{ab}}$ & $0.99 \pm 0.12^{\mathrm{ab}}$ & $0.89 \pm 0.08^{\mathrm{ab}}$ & $0.80 \pm 0.11^{\mathrm{abc}}$ \\
\hline 30 & $1.35 \pm 0.22^{\mathrm{bcd}}$ & $1.70 \pm 0.34^{\mathrm{ab}}$ & $1.90 \pm 0.12^{\mathrm{a}}$ & $1.17 \pm 0.50^{\mathrm{cd}}$ & $0.44 \pm 0.31^{\mathrm{e}}$ & $1.41 \pm 0.18^{\mathrm{bcd}}$ & $1.76 \pm 0.19^{\mathrm{ab}}$ & $1.58 \pm 0.24^{\mathrm{abc}}$ & $1.08 \pm 0.28^{\mathrm{d}}$ \\
\hline 60 & $3.39 \pm 0.38^{\mathrm{b}}$ & $3.77 \pm 0.15^{\mathrm{b}}$ & $4.51 \pm 0.32^{\mathrm{a}}$ & $2.63 \pm 0.81^{\mathrm{cd}}$ & $1.32 \pm 0.16^{\mathrm{e}}$ & $3.20 \pm 0.35^{\mathrm{bc}}$ & $3.63 \pm 0.88^{\mathrm{b}}$ & $2.47 \pm 0.35^{\mathrm{d}}$ & $1.51 \pm 0.23^{\mathrm{e}}$ \\
\hline
\end{tabular}

${ }^{\mathrm{a}-\mathrm{e}}$ Means for the same parameter and day of ripening with different superscripts differ $(P \leq 0.05)$

${ }^{1}$ Treatments: $2 \mathrm{P} 1,3 \mathrm{P} 1,4 \mathrm{P} 1$, and $5 \mathrm{P} 1$ = cheeses treated at 200, 300, 400, and $500 \mathrm{MPa}$, respectively, on the first day of manufacturing; $2 \mathrm{P} 15$, $3 \mathrm{P} 15$, 4P15, and $5 \mathrm{P} 15=$ cheeses treated at 200, 300, 400, and $500 \mathrm{MPa}$, respectively, at $15 \mathrm{~d}$ of manufacturing.

Table 7. Mean values \pm SD of hydrophobic and hydrophilic peptides and the ratio of hydrophobic to hydrophilic peptides (chromatograph units/mg of DM) in the watersoluble fraction of control and high-pressure (HP)-treated ewe milk cheeses at $30 \mathrm{~d}$ of ripening

HP treatment ${ }^{1}$

\begin{tabular}{|c|c|c|c|c|c|c|c|c|c|}
\hline Item & Control & $2 \mathrm{P} 1$ & $3 \mathrm{P} 1$ & $4 \mathrm{P} 1$ & $5 \mathrm{P} 1$ & $2 \mathrm{P} 15$ & $3 \mathrm{P} 15$ & $4 \mathrm{P} 15$ & $5 \mathrm{P} 15$ \\
\hline Hydrophobic & $2,956 \pm 84^{\mathrm{a}}$ & $2,169 \pm 340^{b}$ & $1,997 \pm 197^{b c}$ & $2,082 \pm 104^{b}$ & $1,720 \pm 299^{c}$ & $2,129 \pm 19^{b}$ & $2,169 \pm 41^{\mathrm{b}}$ & $2,159 \pm 28^{\mathrm{b}}$ & $2,103 \pm 101^{b}$ \\
\hline Hydrophilic & $254 \pm 34^{\mathrm{a}}$ & $201 \pm 64^{\mathrm{ab}}$ & $225 \pm 13^{\mathrm{a}}$ & $207 \pm 39^{\mathrm{ab}}$ & $134 \pm 24^{\mathrm{b}}$ & $195 \pm 4^{\mathrm{ab}}$ & $227 \pm 7^{\mathrm{a}}$ & $224 \pm 26^{\mathrm{a}}$ & $220 \pm 40^{\mathrm{a}}$ \\
\hline Ratio & $11.76 \pm 1.45^{\mathrm{ab}}$ & $11.72 \pm 2.14^{\mathrm{ab}}$ & $8.85 \pm 0.36^{b}$ & $10.18 \pm 1.76^{\mathrm{ab}}$ & $12.99 \pm 1.93^{\mathrm{a}}$ & $10.90 \pm 0.32^{\mathrm{ab}}$ & $9.57 \pm 0.44^{\mathrm{ab}}$ & $9.75 \pm 1.24^{\mathrm{ab}}$ & $10.29 \pm 0.79^{\mathrm{ab}}$ \\
\hline
\end{tabular}

${ }^{\mathrm{a}-\mathrm{c}}$ Means for the same parameter with different superscripts differ $(P \leq 0.05)$

${ }^{1}$ Treatments: $2 \mathrm{P} 1,3 \mathrm{P} 1,4 \mathrm{P} 1$, and $5 \mathrm{P} 1=$ cheeses treated at $200,300,400$, and $500 \mathrm{MPa}$, respectively, on the first day of manufacturing; $2 \mathrm{P} 15$, $3 \mathrm{P} 15$, $4 \mathrm{P} 15$, and $5 \mathrm{P} 15=$ cheeses treated at $200,300,400$, and $500 \mathrm{MPa}$, respectively, at $15 \mathrm{~d}$ of manufacturing. 
that were found in these cheeses and also evidenced by the highest amount of FAA present in $3 \mathrm{P} 1$ cheeses (Table 6). These results suggest that treatment at $300 \mathrm{MPa}$ applied on the first day of ripening could induce changes to the cheese matrix, which enhanced the susceptibility of cheese to proteolysis. In addition, the peptidases may have been released due to cell lysis by means of the pressure treatment, accelerating the contact between substrate and enzyme.

The release of amino acids in cheeses clearly indicates aminopeptidase activity. On the first day of ripening, the HP-treated cheeses showed lower levels of FAA than control cheeses (Table 6) in accordance with the lower aminopeptidase activity observed (Table 3). An initial reduction in peptidolytic activity in cheese immediately after HP treatment has been described elsewhere (Sendra et al., 2000). The amount of FAA increased during ripening, and at $15 \mathrm{~d}$ of ripening the highest value of FAA was found in 3P1 cheeses agreeing with the highest aminopeptidase activity found in these cheeses. This increase in FAA levels could be explained as result of rapid peptides degradation, which agreed with the lowest level of hydrophobic peptides (Table 7) and associated with the earlier starter lysis done by the HP treatment. Crow et al. (1995) established that when starter lysis occurs, the levels of FAA in cheese increase and bitterness is reduced, leading to a better flavor. On the other hand, at $60 \mathrm{~d}$ of ripening, FAA levels in 4P1, 4P15, 5P1, and 5P15 were 1.28-, 1.37-, 2.56-, and 2.24-fold lower than untreated cheeses, respectively. These results agree with previous works (Juan et al., 2004; Wick et al., 2004) and show that pressures $\geq 400 \mathrm{MPa}$ seem to delay FAA development.

A PCA was carried out to correlate the activity of proteolytic enzymes with the primary and secondary proteolysis of cheeses (Figures 1 and 2). Principal component (PC) 1 explained $32.19 \%$ of the variance and correlated positively with chymosin, FAA, residual $\alpha_{\mathrm{s} 1^{-}}$ I-casein, and hydrophobic and hydrophilic peptides, and negatively with the residual para- $\kappa$ - and $\alpha_{\mathrm{s} 1}$-caseins, and the ratio of hydrophobic to hydrophilic peptides (Figure 1a). Accordingly, PC 1 was defined as a degree of proteolysis factor. The $\alpha_{\mathrm{s} 2^{-}}$and $\beta$-caseins showed high negative loading with PC 2, which explained $19.18 \%$ of the variance (Figure 1a) and could be defined as plasmin factor. The LDH and Leu- $p$-NA activities correlated positively with PC 3 (Figure 2a), and accordingly, this factor was defined as a lytic factor. Plotting of cheeses at $60 \mathrm{~d}$ of ripening in the 2-dimensional coordinate system (Figures $1 \mathrm{~b}$ and $2 \mathrm{~b}$ ) shows that pressures of $500 \mathrm{MPa}$ applied on the first day of ripening decelerated the proteolysis of cheeses. The 5P1 cheeses showed the lowest degradation of para- $\kappa$ - and $\alpha_{\mathrm{s} 1}$-casein and the lowest $\alpha_{\mathrm{s} 1}$-I-casein, peptides, and
FAA levels. On the other hand, HP treatments at $>200$ $\mathrm{MPa}$ applied on the first day of ripening, and all HP treatments applied at $15 \mathrm{~d}$ of ripening accelerated the degradation of $\alpha_{\mathrm{s} 2^{-}}$and $\beta$-caseins mainly due to the plasmin action (Figure 1b). The treatment of $300 \mathrm{MPa}$ applied on the first day of ripening produced a prompt starter lysis, increasing the aminopeptidase activity and the levels of FAA (Figure 2b).

\section{CONCLUSIONS}

Primary proteolysis, analyzed by the casein degradation, was enhanced by pressures of 300 and $400 \mathrm{MPa}$ applied on the first day of ripening and with 200 to 500 $\mathrm{MPa}$ applied on d 15 of manufacturing, probably as a consequence of the barostability of plasmin activity combined with conformational changes on the cheese matrix, which enhanced the susceptibility of casein to chymosin and plasmin attacks. However, pressures of $500 \mathrm{MPa}$ applied on the first day of ripening resulted in large inactivation of residual chymosin and reduced the primary proteolysis of ewe milk cheeses.

Secondary proteolysis, which gives the proportion of peptides and FAA, was also enhanced with the treatment at $300 \mathrm{MPa}$ applied on the first day of ripening. The 3P1 cheeses had the lowest hydrophobic peptides and the highest FAA content due to the highest peptidolytic activity. The HP treatment favored the lysis of starter bacteria enhancing the release of intracellular aminopeptidases into the cheese matrix. This treatment could also have also a beneficial effect on flavor quality because 3P1 cheeses contained lower amounts of hydrophobic peptides and the lowest hydrophobicity index, both parameters associated with cheese bitterness. On the other hand, the treatment of $500 \mathrm{MPa}$ decreased the secondary proteolysis of ewe milk cheeses. These cheeses showed the lowest amounts of peptides and FAA, probably due to the reduction of starter bacteria and enzyme inactivation by the pressure.

These results suggest that $\mathrm{HP}$ treatment at $300 \mathrm{MPa}$ applied on the first day of ripening could be used to accelerate the proteolysis of ewe milk cheeses. In contrast, the treatment at $500 \mathrm{MPa}$ applied on the first day of ripening would decelerate it.

\section{ACKNOWLEDGMENTS}

The authors acknowledge the Comisión Interministerial de Ciencia y Tecnología for the financial support given to this investigation (CICYT AGL2000-1426C02). B. Juan acknowledges a predoctoral fellowship from the Comissionat per a Universitat i Recerca de la Generalitat de Catalunya. 
a)

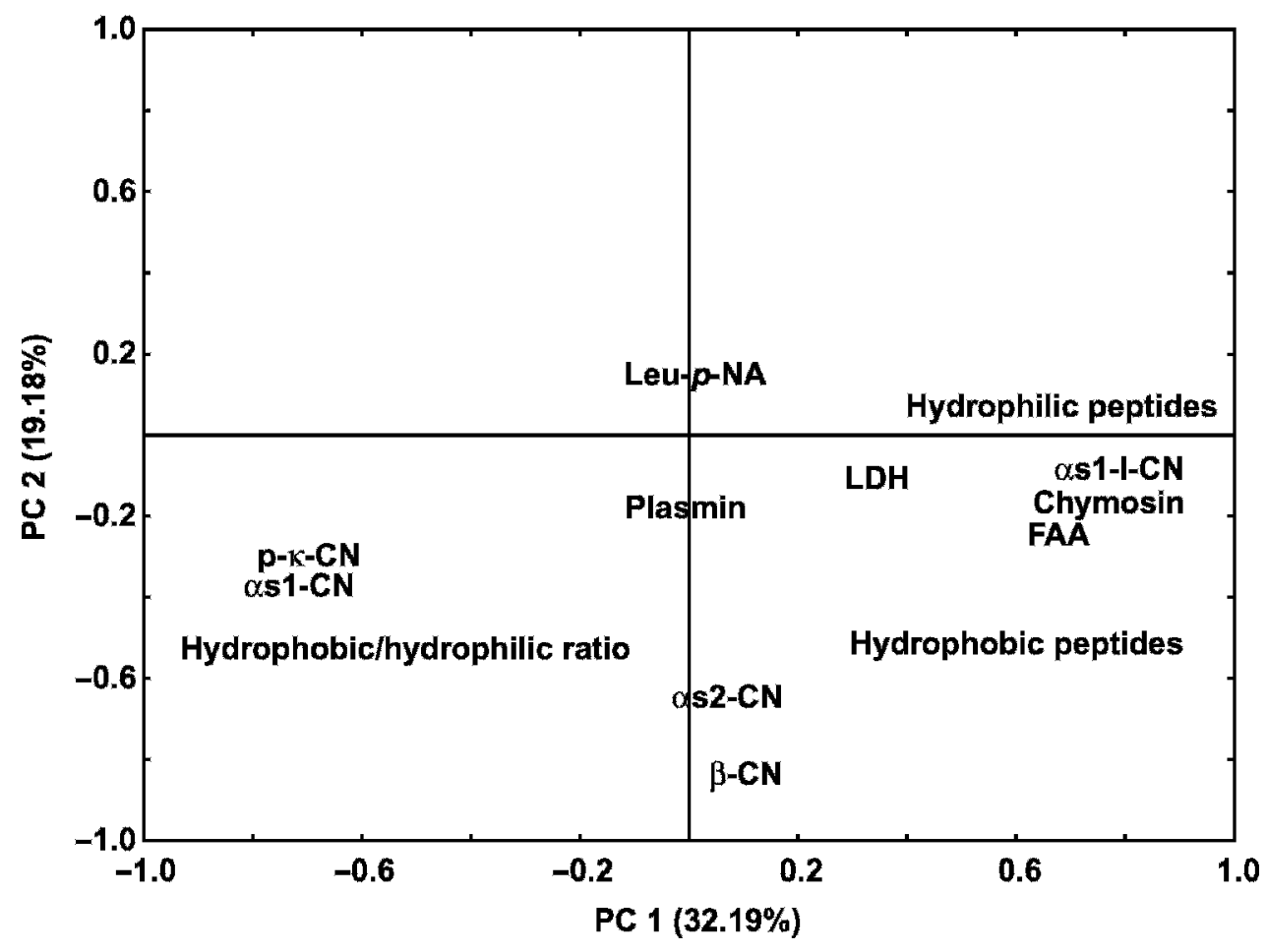

b)

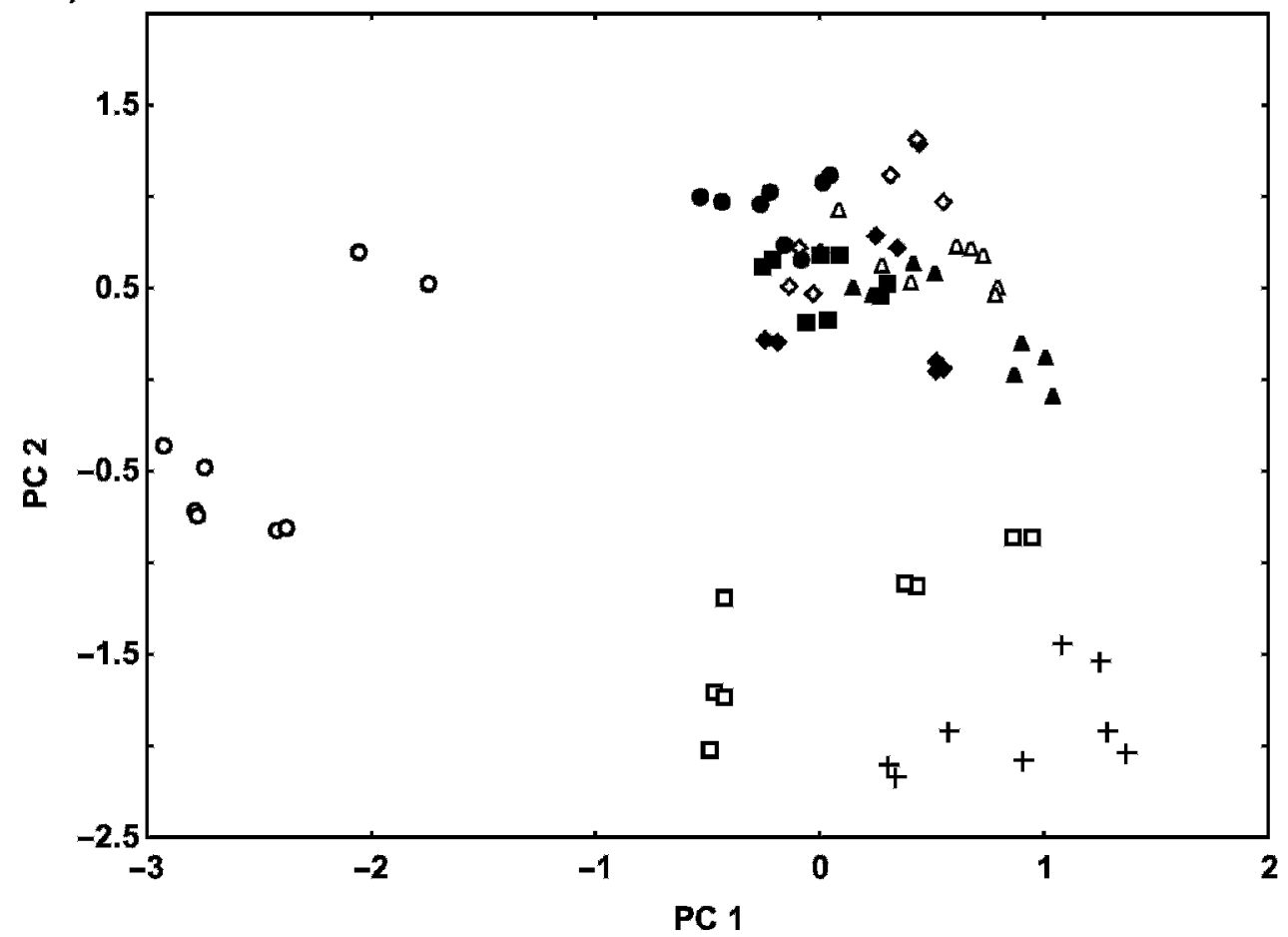

Figure 1. a) Principal components (PC) analysis plot defined by PC 1 and PC 2 showing the distribution of enzymatic activity [lactate dehydrogenase (LDH), aminopeptidase, chymosin, and plasmin] and proteolysis variables [residual caseins, hydrophobic and hydrophilic peptides and their ratio, and total free amino acids (FAA)]. b) Distribution of 60-d-old cheeses in the plane defined by PC 1 and PC 2. Control $(+), 2 \mathrm{P}(\square, \boldsymbol{\square}), 3 \mathrm{P}(\triangle, \boldsymbol{\Delta}), 4 \mathrm{P}(\diamond, \diamond)$, and 5P $(\bigcirc, \bullet)$ cheeses. Open symbols represent P1 cheeses; closed symbols represent P15 cheeses. Leu- $p$-NA = leucine- $p$-nitroanilide. 
a)

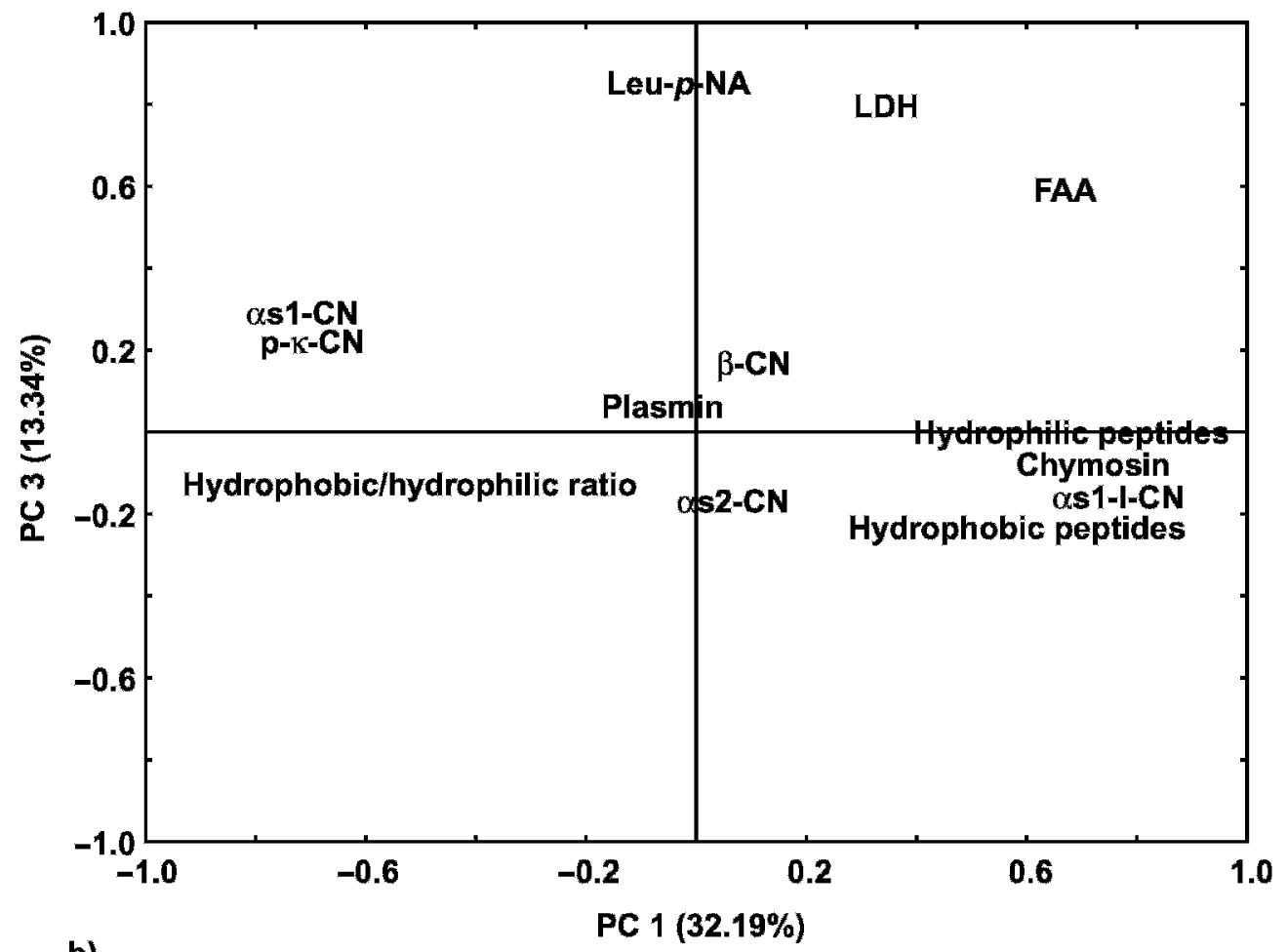

b)

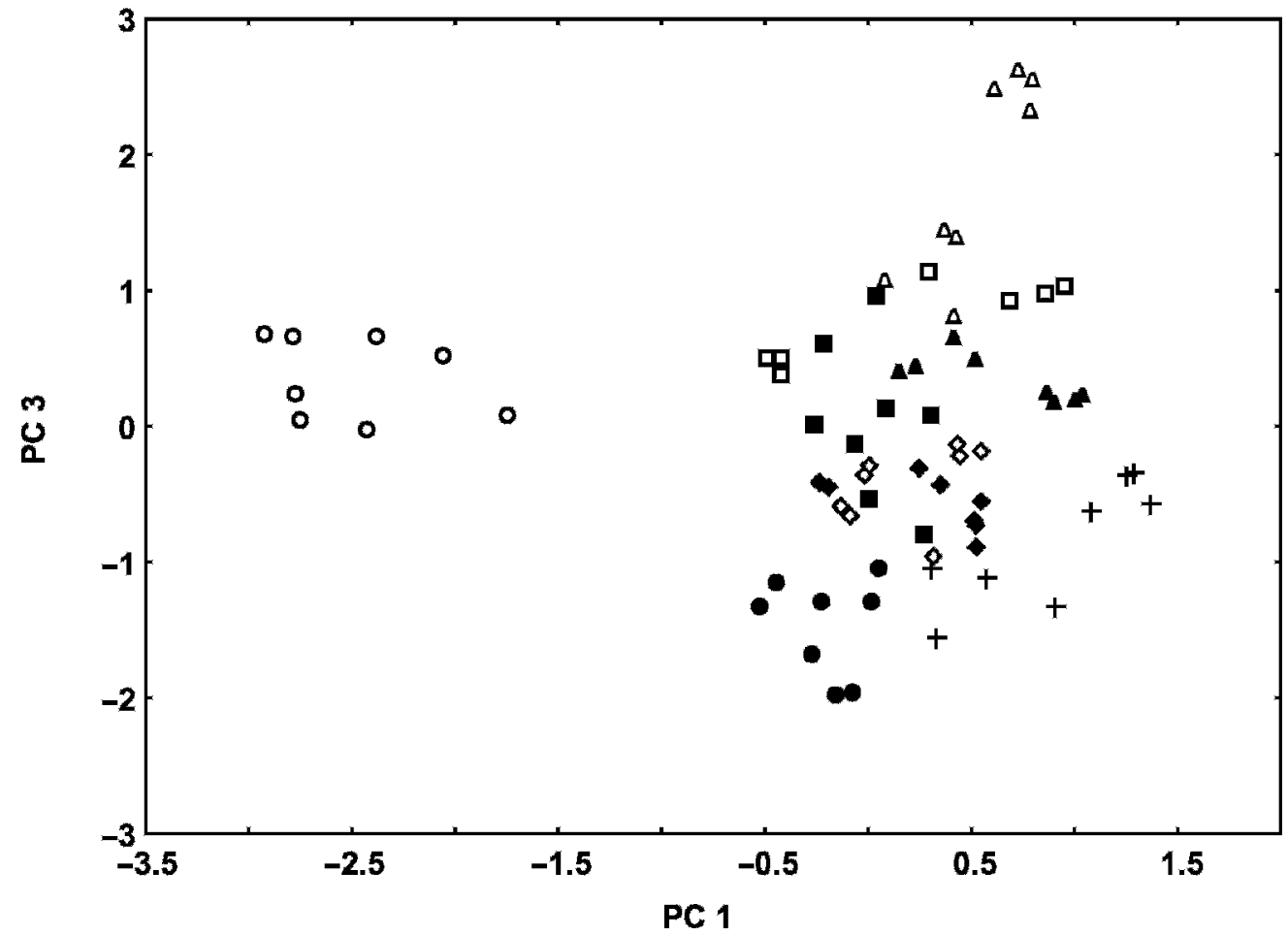

Figure 2. a) Principal components (PC) analysis plot defined by PC 1 and PC 3 showing the distribution of enzymatic activity [lactate dehydrogenase (LDH), aminopeptidase, chymosin, and plasmin] and proteolysis variables [residual caseins, hydrophobic and hydrophilic peptides and their ratio, and total free amino acids (FAA)]. b) Distribution of 60 -d-old cheeses in the plane defined by PC 1 and PC 3. Control $(+), 2 \mathrm{P}(\square, \mathbf{\square}), 3 \mathrm{P}(\triangle, \mathbf{\Delta}), 4 \mathrm{P}(\diamond, \diamond)$, and $5 \mathrm{P}(\bigcirc, \bullet)$ cheeses. Open symbols represent $\mathrm{P} 1$ cheeses; closed symbols represent P15 cheeses. Leu- $p$-NA = leucine- $p$-nitroanilide. 


\section{REFERENCES}

Ávila, M., S. Garde, P. Gaya, M. Medina, and M. Núñez. 2006. Effect of high-pressure treatment and a bacteriocin-producing lactic culture on the proteolysis, texture, and taste of Hispánico cheese. J. Dairy Sci. 89:2882-2893.

Casal, V., and R. Gómez. 1999. Effect of high pressure on the viability and enzymatic activity of mesophilic lactic acid bacteria isolated from caprine cheese. J. Dairy Sci. 82:1092-1098.

Cheftel, J. C. 1992. Effect of high hydrostatic pressure on food constituents: An overview. Pages 195-209 in High Pressure and Biotechnology. Vol. 224. C. Balny, R. Hayashi, K. Heremans, and P. Masson, ed. Coloque INSERM/John Libbey Eurotext, London, UK.

Creamer, L. K., H. F. Zoerb, N. F. Olson, and T. Richardson. 1982. Surface hydrophobicity of $\alpha_{\mathrm{s} 1}$-I, $\alpha_{\mathrm{s} 1}$-casein A and B and its implications in cheese structure. J. Dairy Sci. 65:902-906.

Crow, V. L., F. G. Martley, T. Coolbear, and S. J. Roundhill. 1995. The influence of phage-assisted lysis of Lactococcus lactis subsp. lactis ML8 on Cheddar cheese ripening. Int. Dairy J. 5:451-472.

Desmazeud, M. J., and M. Juge. 1976. Charactérisation de l'activité protéolytique et fractionnement des dipeptidases et des aminopeptidases de Streptococcus thermophilus. Lait 553-554:241-260.

Folkertsma, B., and P. F. Fox. 1992. Use of the Cd-ninhydrin reagent to assess proteolysis in cheese during ripening. J. Dairy Res. 59:217-224.

Fox, P. F. 1989. Acceleration of cheese ripening. Food Biotechnol. $2: 133-185$

Fox, P. F., J. Law, P. L. H. McSweeney, and J. Wallace. 1993. Biochemistry of cheese ripening. Pages 389-438 in Cheese: Chemistry, Physics and Microbiology, 2nd ed. P. F. Fox, ed. Chapman and Hall, London, UK.

Fox, P. F., and P. L. H. McSweeney. 1996. Proteolysis in cheese. Food Rev. Int. 12:457-509.

González del Llano, D., M. C. Polo, and M. Ramos. 1995. Study of proteolysis in artisanal cheeses: High performance liquid chromatography of peptides. J. Dairy Sci. 78:1018-1024.

Huppertz, T., P. F. Fox, and A. L. Kelly. 2004. Susceptibility of plasmin and chymosin in Cheddar cheese to inactivation by high pressure. J. Dairy Res. 71:496-499.

Hurley, M. J., B. M. O’Driscoll, A. L. Kelly, and P. L. H. McSweeney. 1999. Novel assay for the determination of residual coagulant activity in cheese. Int. Dairy J. 9:553-558.

IDF. 1982. Cheese and processed cheese. Determination of the total solids content. Standard 4 A. Int. Dairy Fed., Brussels, Belgium.

IDF. 1993. Milk determination of the total nitrogen content. Standard 20B. Int. Dairy Fed., Brussels, Belgium.

Juan, B., V. Ferragut, B. Guamis, M. Buffa, and A. J. Trujillo. 2004. Proteolysis of high pressure-treated ewe's milk cheese. Milchwissenschaft 59:616-619.

Kolakowski, P., A. Reps, and A. Babuchowski. 1998. Characteristics of pressurised ripened cheeses. Pol. J. Food Nutr. Sci. 7:473-482.

Krasowska, M., A. Reps, and A. Jankowska. 2005. Effect of high pressures on the activity of selected strains of lactic acid bacteria. Milchwissenschaft 60:382-385.

Kuchroo, N. C., and P. F. Fox. 1982. Soluble nitrogen in cheese: Comparison of extraction procedures. Milchwissenschaft 37:331-334.

Kunugi, S. 1993. Modification of biopolymer functions by high pressure. Prog. Polym. Sci. 18:805-838.

Malone, A. S., T. H. Shellhammer, and P. D. Courtney. 2002. Effects of high pressure on the viability, morphology, lysis and cell wall activity of Lactococcus lactis subsp. cremoris. Appl. Environ. Microbiol. 68:4357-4363.

Malone, A. S., C. Wick, T. H. Shellhammer, and P. D. Courtney. 2003. High pressure effects on proteolytic and glycolytic enzymes involved in cheese manufacturing. J. Dairy Sci. 86:1139-1146.

Marcos, A., J. Fernández-Salguero, and M. A. Esteban. 1978. Hidrólisis relativa de las caseínas del queso tipo Manchego maduro y primeros productos de su degradación proteolítica. Arch. Zootec. 27:341-350.

McSweeney, P. L. H., and P. F. Fox. 1997. Characterizaton of proteolysis in cheese during ripening. Lait 77:41-76.
Messens, W., K. Dewettinck, J. Van Camp, and A. Huyghebaert. 1998. High pressure brining of Gouda cheese and its effect on the cheese serum. Lebensm. Wiss. Technol. 31:552-558.

Messens, W., J. Estepar-Garcia, K. Dewettinck, and A. Huyghebaert. 1999. Proteolysis of high-pressure-treated Gouda cheese. Int. Dairy J. 9:775-782.

Messens, W., I. Foubert, K. Dewettinck, and A. Huyghebaert. 2000. Proteolysis of a high-pressure-treated smear-ripened cheese. Milchwissenschaft 55:328-332.

O'Reilly, C., P. M. O'Connor, P. M. Murphy, A. L. Kelly, and T. P. Beresford. 2000. The effect of exposure to pressure of $50 \mathrm{MPa}$ on Cheddar cheese ripening. Innov. Food Sci. Emerg. Technol. 1:109-117.

O'Reilly, C. E., A. L. Kelly, P. M. Murphy, and T. P. Beresford. 2001. High pressure treatment: Applications in cheese manufacture and ripening. Trends Food Sci. Technol. 12:51-59.

O’Reilly, C., P. M. O'Connor, P. M. Murphy, A. L. Kelly, and T. P. Beresford. 2002. Effects of high-pressure treatment on viability and autolysis of starter bacteria and proteolysis in Cheddar cheese. Int. Dairy J. 12:915-922.

O'Reilly, C. E., A. L. Kelly, J. C. Oliveira, P. M. Murphy, M. A. E. Auty, and T. P. Beresford. 2003. Effect of varying high-pressure treatment conditions on acceleration of ripening of Cheddar cheese. Innov. Food Sci. Emerg. Technol. 4:277-284.

Rampilli, M., and V. Raja. 1998. Observations on residual plasmin and plasminogen activities in cheese. Sci. Tecn. Latt. Cas. 49:341-350.

Recio, I., and C. Olieman. 1996. Determination of denatured serum proteins in the casein fraction of heat-treated milk by capillary zone electrophoresis. Electrophoresis 17:1228-1233.

Reps, A., P. Kolakowski, K. Wisniewska, and F. Dajnowiec. 1998. The effect of high pressure on microorganisms and enzymes of ripening cheeses. Pages 265-270 in High Pressure Food Science. R. Soc. Chem. Biosci. Chem., Cambridge, UK.

Reps, A., P. Kolakowski, K. Wisniewska, and M. Krasowska. 2003. The effect of high pressures on proteolytic enzymes in ripened cheeses. Milchwissenschaft 58:138-140.

Saldo, J., P. L. H. McSweeney, E. Sendra, A. L. Kelly, and B. Guamis. 2002. Proteolysis in caprine milk cheese treated by high pressure to accelerate cheese ripening. Int. Dairy J. 12:35-44.

Scollard, P. G., T. P. Beresford, E. C. Needs, P. M. Murphy, and A. L. Kelly. 2000. Plasmine activity, $\beta$-lactoglobulin denaturation and proteolysis in high pressure treated milk. Int. Dairy J. 10:835-841.

Sendra, E., J. Saldo, M. Capellas, and B. Guamis. 2000. Decrease of free amino acids in high-pressure treated cheese. High Pressure Res. 19:423-426.

Sousa, M. J., Y. Ardõ, and P. L. H. McSweeney. 2001. Advances in the study of proteolysis during cheese ripening. Int. Dairy J. 11:327-345.

Tan, P. S. T., M. P. Chapot-Chartier, K. M. Pos, M. Rousseau, C. Y. Boquien, J. C. Gripon, and W. N. Konings. 1992. Localization of peptidases in lactococci. Appl. Environ. Microbiol. 58:285-290.

Trujillo, A. J., M. Capellas, M. Buffa, C. Royo, R. Gervilla, X. Felipe, E. Sendra, J. Saldo, V. Ferragut, and B. Guamis. 2000a. Application of high pressure treatment for cheese production. Food Res. Int. 33:311-316.

Trujillo, A. J., B. Guamis, and C. Carretero. 2000b. A procedure for the manufacture of goat milk cheese with controlled-microflora by means of high hydrostatic pressure. Food Chem. 69:73-79.

Trujillo, A. J., M. Pavia, V. Ferragut, I. Casals, and B. Guamis. 2000c. Analysis of proteins in milk and cheese by capillary zone electrophoresis. Pages 239-255 in Recent Research Developments in Agricultural and Food Chemistry. Research Signpost Vol 4. Part II. S. G. Pandalai, Trivandrum, India.

Wick, C., U. Nienaber, O. Anggraeni, T. H. Shellhammer, and P. D. Courtney. 2004. Texture, proteolysis and viable lactic acid bacteria in commercial Cheddar cheeses treated with high pressure. J. Dairy Res. 71:107-115.

Wilkinson, M. G. 1999. Cheese: Chemistry, Physics and Microbiology. Vol. 1. P. F. Fox, ed. Aspen Publishers Inc., Gaithersburg, MD.

Wilkinson, M. G., and K. N. Kilcawley. 2005. Mechanisms of incorporation and release of enzymes into cheese during ripening. Int. Dairy J. 15:817-830. 